\title{
Ocular Morbidity in Rural Communities in Imo State South East Nigeria
}

\author{
Eberechukwu Ogbeanu Achigbu*, Kenneth Chukwuma Dike, Angela Chinwe Uwakwem, \\ Emmanuel U. Ogborogu, Vivien Chinenye Nkwogu \\ Department of Ophthalmology, Federal Medical Centre, Owerri, Nigeria \\ Email: *ebyachigbu1@gmail.com, kenteyes2007@yahoo.com, auwakwem@gmail.com, \\ emmanuelogborogu@yahoo.com,chinenyenkwogu@yahoo.com
}

Received 7 July 2016; accepted 28 August 2016; published 31 August 2016

Copyright (C) 2016 by authors and Scientific Research Publishing Inc.

This work is licensed under the Creative Commons Attribution International License (CC BY).

http://creativecommons.org/licenses/by/4.0/

c) (i) Open Access

\begin{abstract}
Introduction: Approximately $80 \%$ of blindness is avoidable. Poverty and ignorance have been reported as factors responsible for many cases. There is a poor uptake of orthodox eye health services and an increase in the consultation of traditional healers in the developing countries. Age, level of education, occupation, cost and accessibility to these traditional healers have been reported as predictors of this behavior. The absence of eye care services at the rural areas have necessitated the use of free eye screening/treatment as tools for educating and offering eye care to these rural dwellers. Various patterns of eye diseases have been described in different regions and localities within and outside Nigeria. This study aims to determine the pattern and prevalence of ocular disorders in some rural areas of Imo state where primary eye care facilities are scarce with a view to making recommendations to the health authorities for proper planning of eye care services in the state. Methods: This was a retrospective review of data generated from self-selected patients during the free eye screening organized in each of the 3 senatorial zones of Imo state by the Federal Medical Centre Owerri, Imo state. The study was approved by the Ethics Committee of Federal Medical Centre, Owerri, Imo State, Nigeria. Results: A total of 1973 subjects participated in the outreach. There were $1111(56.3 \%)$ females and $862(43.7 \%)$ males giving a ratio of $1.3: 1$. The most common causes of ocular morbidity were refractive error $(31.6 \%)$, glaucoma $(23.5 \%)$, presbyopia $(17 \%)$, and cataract $(12.5 \%)$. Refractive error, glaucoma, and cataract were significantly associated with age and sex while presbyopia was only positively associated age. Conclusion: Considering the causes of ocular morbidity noted in this study, there is an urgent need to establish primary eye care services in these remote and rural areas in order to achieve the vision 2020 goal of eliminating avoidable blindness.
\end{abstract}

\footnotetext{
"Corresponding author.
} 


\section{Keywords}

\section{Morbidity, Ocular, Prevalence, Rural}

\section{Introduction}

The prevalence of blindness and visual impairment among those 40 years and above in Nigeria were $4.2 \%$ and $1.5 \%$ respectively in the National survey conducted in Nigeria [1]. This prevalence varied across the geo political zones of the country with the highest for blindness recorded in the North East (6.1\%) and the lowest in the South West zone (2.8\%) of the country [1]. The South East Zone in which Imo state is located had a blindness prevalence of $4.6 \%$. Blindness in this survey was associated with increasing age, being female, poor literacy, and residence in the North [1].

About $80 \%$ of blindness is avoidable (preventable or treatable) and most of the world's blind live in developing countries such as Nigeria [2]. Poverty and ignorance have been reported as factors responsible for many cases of avoidable blindness [3]. Most patients in Nigeria who require eye health services remain at home until they become irreversibly blind or consult traditional healers. Age, level of education, occupation, cost and accessibility to these traditional healers have been reported as predictors of the patronage of these services [3]-[7] and poor uptake of orthodox eye health services.

Free eye screenings and surgeries have been utilized by various eye care institutions, governmental and nongovernmental organizations as a tool to educate, treat and increase the awareness of a target population to the availability of eye health services in their locality in a bid to reduce the burden of avoidable/treatable blindness in the country.

Worldwide, the pattern of ocular diseases varies from one location to another. However, cataract, glaucoma, conjunctivitis, corneal ulcers, uveitis, refractive errors, pterygium are considered the common ocular disorders [8]. Cataract, refractive errors/low vision, trachoma, onchocerciasis, and vitamin A deficiency/other causes of childhood blindness were determined to be responsible for $75 \%$ of all blindness worldwide [9]. These are treatable and preventable causes of blindness.

Some studies [8] [10]-[12] carried out in Nigeria have shown refractive error, conjunctivitis and cataract as the three most common cause of ocular morbidity.

Similarly, Osahon et al. [9] following an outreach in Edo and Delta states of Nigeria reported on the pattern of eye diseases with uncorrected refractive error being the commonest eye disease followed by cataract, glaucoma and conjunctivitis. Knowledge of the pattern and socio-demographic characteristics of a disease is necessary for the planning and execution of healthcare policies in the country especially in a society as ours where the socioeconomic burden of the diseases is domiciled and the necessary resources are lacking.

This study was undertaken to determine the pattern and prevalence of eye diseases in the rural areas of Imo State where primary eye care facilities are scarce with a view to making our findings available to the necessary health authorities for proper planning of eye care.

\section{Subjects and Methods}

\subsection{Study Area}

This study was carried out in the 3 senatorial zones of Imo State namely Owerri, Okigwe and Orlu. These are geo-political zones created to aid equal distribution of resources. The Owerri zone is made up of 9 Local Government Areas (LGA). Okigwe has 6 while Orlu has 12 LGAs. Imo State is one of the 5 states in the south eastern part of Nigeria. It has a population of over 4.8 million from the 2006 census and the population density varies from 230 - 1400 people per square kilometer.

The people of Imo state are mostly farmers but there are also skilled and un-skilled workers.

\subsection{Study Design}

This was a retrospective review of data generated from self-selected (walk-in) patients during the free medical outreaches organized in each of the 3 senatorial zones of Imo state by the Federal Medical Centre Owerri, Imo 
State. The community leaders were visited prior to the outreach to explain the purpose of the outreach and for permission to enter the community. The site for the proposed outreach and the dates were also decided on when approval was received. They were assured that they would not be exposed to any harm.

The residents in each senatorial zone were then informed of the outreach at least one week prior to the date through repeated announcements over the radio, announcements in the churches, and by the village town criers. The outreach was carried out over 4 weeks from November to December 2013.

The participants in each senatorial zone visited were screened in one day and those that required surgery were operated upon over the remaining days of the week.

Information was collected on the age and sex of the participants and the types of ocular disorders diagnosed after a clinical evaluation.

The visual acuity of the participants was determined using a Snellen's visual acuity chart. They were grossly assessed first with the 6/18 line. The pinhole was then used for further assessment of participants who could not read the 6/18 line. If the vision improves with pinhole, they are diagnosed to have refractive error and sent to the Optometrists for refraction after carrying out anterior and posterior segments examination with pen torch and direct ophthalmoscope respectively. The types of refractive were however, not considered in this study. Those who had no improvement with pin hole were also further examined. Gutt Tropicamide was used for dilatation of the pupils where necessary.

\subsection{Data Management}

Data collected were analysed with SPSS version 20 (2012) and presented in tables and charts. Chi square was used to compare variables. A p-value of $<0.05$ was considered significant.

\subsection{Ethical Considerations}

This study was approved by the Ethics Committee of Federal Medical Centre, Owerri, Imo State, Nigeria.

The participants with glaucoma were given eye drops and asked to return to the eye clinic of FMC Owerri for further evaluation and follow up. Those with refractive errors and presbyopia were refracted on site and the requisite spectacle provided for them. The others with various ailments were treated where necessary. Prescriptions were also given to the participants to purchase their drugs from the pharmacy if the drugs were not available in the outreach stock.

\section{Results}

A total of 1973 participants with an average age of 48 years +/- 17.4 standard deviation were examined in 4 communities in the 3 senatorial zones of Imo State. Mbaise had 842 respondents, Ngor Okpala 418, Izombe 392 and Mbano 321 respondents respectively.

The minimum age reported was 6 years and maximum 100 years.

There were 1111 (56.3\%) females and 862 (43.7\%) males giving a ratio of 1.3:1.

\section{Discussion}

More females than males participated in the outreaches. This is different from the general belief that more males are seen in the clinics than females [3] [13]. The finding in our study was collaborated by other studies [14]-[16]. This may be attributed to the fact that this was a free outreach which was brought literally to the door steps of these women who ordinarily are kept busy with household chores and no extra funds for their health care.

The age range (Table 1) was similar to what was seen in other outreaches with a mean age of 48 years [16] [17].

The most common type of ocular disorder noted in this study (Table 2) was refractive error (31.6\%) similar to the findings in south west and south south part of Nigeria [10] [11] [18] [19]. Other studies however, reported cataract, [14] [16] and conjunctivitis [17] as the most common ocular disorders. Uncorrected Refractive error in the Nigerian National Blindness Survey was shown to be the commonest cause of mild (77.9\%) and moderate (57.1\%) [1] visual impairment and the leading cause of visual impairment at a prevalence of $43 \%$ [20]. It was concluded that refractive error was responsible for visual impairment in 2.46 million adults over 40 years in Nigeria [1]. Considering that children were participants in this study; this finding is very significant as uncorrected 
Table 1. Age group of the participants.

\begin{tabular}{cccc}
\hline Age & Group & Frequency & Percent \\
\hline $1-10$ & years & 23 & 1.2 \\
$11-20$ & years & 142 & 7.2 \\
$21-30$ & years & 150 & 7.6 \\
$31-40$ & years & 325 & 16.5 \\
$41-50$ & years & 460 & 23.3 \\
$51-60$ & years & 379 & 19.2 \\
$61-70$ & years & 320 & 16.2 \\
$71-80$ & years & 140 & 7.1 \\
$81-90$ & years & 29 & 1.5 \\
$91-100$ & years & 5 & 0.3 \\
Total & 1973 & 100.0 & 100.0 \\
\hline
\end{tabular}

Majority (23.3\%) of the participants were within the 41 - 50 years age group followed by the $51-60$ years age group.

Table 2. Types of ocular disorders.

\begin{tabular}{|c|c|c|}
\hline Ocular Disorders & Frequency & Percentage \\
\hline Cataract & 247 & $12.5 \%$ \\
\hline Refractive Error & 623 & $31.6 \%$ \\
\hline Conjunctivitis & 123 & $6.2 \%$ \\
\hline Glaucoma & 464 & $23.5 \%$ \\
\hline ARMD & 33 & $1.7 \%$ \\
\hline Pterygium & 66 & $3.3 \%$ \\
\hline Glaucoma suspect & 32 & $1.6 \%$ \\
\hline Presbyopia & 335 & $17.0 \%$ \\
\hline Allergy & 179 & $9.1 \%$ \\
\hline VKC & 2 & $0.1 \%$ \\
\hline Diabetic retinopathy & 11 & $0.6 \%$ \\
\hline Optic neuritis & 7 & $0.4 \%$ \\
\hline Pseudophakia & 4 & $0.2 \%$ \\
\hline Conjunctival cyst & 5 & $0.3 \%$ \\
\hline Ocular pain & 5 & $0.3 \%$ \\
\hline Maculopathy & 8 & $0.4 \%$ \\
\hline Pingueculum & 3 & $0.2 \%$ \\
\hline Blunt trauma & 2 & $0.1 \%$ \\
\hline Anterior uveitis & 2 & $0.1 \%$ \\
\hline Corneal scar & 2 & $0.1 \%$ \\
\hline Retinitis pigmentosa & 2 & $0.1 \%$ \\
\hline Phthisis bulbi & 1 & $0.1 \%$ \\
\hline
\end{tabular}

Refractive error at a prevalence of $31.6 \%$ was the commonest cause of ocular morbidity among the participants while glaucoma $(23.5 \%)$ and presbyopia $(17.0 \%)$ were the $2^{\text {nd }}$ and $3^{\text {rd }}$ respectively. One hundred and nineteen (48.2\%) had mature cataract while 128 (51.8\%) had immature cataract. 
refractive error is a cause of poor school performance and absenteeism. Moreover, it can adversely affect the output of the worker and the quality of life of those plagued by it. Refractive error was significantly associated with age and sex (Table 3 ) with the females having a 1.5 times risk of presenting with the disorder.

Glaucoma (23.5\%) as shown in Table 2 was the second most common ocular disorder noted similar to the study in Kebbi and kaduna states of Nigeria [16] [21]. This finding however, is at variance with the findings of similar studies in other geo political zones of Nigeria and Africa [3] [7] [22]. In Osun state of Nigeria, glaucoma was reported as the commonest cause of posterior segment disorders at a prevalence of $6.6 \%$ [14].

Glaucoma remains the commonest cause of irreversible blindness globally and $3^{\text {rd }}$ major cause of visual impairment at 2.0\% [2]. The high prevalence noted in this study is also consistent with the findings of the National survey where glaucoma accounted for $23 \%$ of blindness in the Guinea forest Savannah zone in which Imo state is located [1]. The irreversible nature of glaucoma damage demands that all should be done to prevent this cause of avoidable blindness. Thirty two (1.6\%) of the participants were designated glaucoma suspects. These would require a regular follow up to prevent permanent loss of vision with its attendant economic loss. There was a positive correlation between glaucoma, age and sex with the males showing a 1.1 times risk of presenting with the disease (Table 3).

Presbyopia at $17 \%$ (Table 2) was the third most common ocular disorder similar in prevalence to the findings in Ethopia [17]. Larger figures were reported by Omoti (68.6\%) and Akinsola (61\%) in their studies [3] [11].

Table 3. Correlation analysis of the common ocular disorders.

\begin{tabular}{|c|c|c|c|}
\hline Sex/Age & Refractive Error & P-Value & Odds Ratio \\
\hline Male & 243 & 0.004 & 0.851 \\
\hline Female & 380 & & 1.126 \\
\hline \multirow[t]{2}{*}{ Age } & & 0.000 & \\
\hline & Glaucoma & & \\
\hline Male & 247 & 0.000 & 1.306 \\
\hline Female & 217 & & 0.789 \\
\hline \multirow[t]{2}{*}{ Age } & & 0.000 & \\
\hline & Presbyopia & & \\
\hline Male & 128 & 0.026 & 0.853 \\
\hline Female & 207 & & 1.120 \\
\hline \multirow[t]{2}{*}{ Age } & & 0.000 & \\
\hline & Cataract & & \\
\hline Male & 70 & 0.001 & 1.377 \\
\hline Female & 49 & & 0.719 \\
\hline \multirow[t]{2}{*}{ Age } & & 0.000 & \\
\hline & Allergies & & \\
\hline Male & 60 & 0.004 & 0.750 \\
\hline Female & 119 & & 1.202 \\
\hline \multirow[t]{2}{*}{ Age } & & 0.000 & \\
\hline & Diabetic Retinopath & & \\
\hline Male & 8 & 0.052 & 1.67 \\
\hline Female & 3 & & 0.48 \\
\hline Age & & 0.000 & \\
\hline
\end{tabular}

The common causes of ocular morbidity among the participants compared above were all significantly associated with age and sex except diabetic retinopathy which was significantly associated with age but not sex. 
Their figures though were a percentage of the entire persons presenting with refractive error. Although not a blinding condition, presbyopia causes significant near visual impairment which can severely retard the work output, performance and quality of life of the subjects. The relationship between presbyopia and gender (Table 3) was not statistically significant however; there was a positive relationship with age as depicted in Table 3. Females showed a 1.6 risk of presenting with presbyopia.

Cataract, the commonest cause of severe visual impairment and blindness in the national survey at $45.3 \%$ and $43.0 \%$ respectively was the $4^{\text {th }}$ significant cause of ocular morbidity in these rural dwellers at a prevalence of $12.5 \%$ (Table 2). Almost half (48.2\%) of these consistent with the national survey findings had blinding cataract and were operated upon free of any charges. Other studies had varying prevalence such as $25.9 \%$ in Osun, $16.4 \%$ in Ethiopia with > 50\% accounting for bilateral blindness and low vision, 32.3\% in North West Nigeria, 26. I\%. in Benin South South Nigeria [3] [14] [16] [17]. Age related cataract is the commonest cause of cataract globally. This calls for a concerted effort by all stake holders to continuously reduce the burden of cataract blindness by clearing up the backlog of patients with cataract and operating on new cases presenting daily. The Nigerian National survey [23] reported that operable cataract (i.e. visual acuity of $<6 / 60$ ) affects 400,000 people. They estimated that by the year 2020 the number with operable cataract will increase by $43 \%$ to 600,000 if the incidence of cataract blindness/severe visual impairment and cataract surgical coverage remains essentially unchanged [23]. Age and gender were statistically associated with cataract with men showing a higher risk of presentation (Table 3).

Allergies at 9.1\% (179), was another significant cause of ocular morbidity (Table 2). They can be self-limiting but in some cases may be complicated by bacterial conjunctivitis or corneal ulcers. It is therefore not surprising that one hundred and twenty three (6.2\%) respondents had conjunctivitis. Both disorders are significant causes of school absenteeism among children. Allergies as shown in table 3 were positively correlated with age and gender with females showing approximately 2 times risk of presenting with the disorder. Allergy was the commonest cause of ocular morbidity in Ethiopia [24].

Diabetic retinopathy (DR) at $0.6 \%$ is very significant because of its potential to cause blindness in those affected due to the chronic nature of the disease and the possible poor glycaemic control which are the hallmarks for its development. Approximately 3 million (2.4\%) Nigerians have diabetes and only about $20 \%$ of them are aware of it [25]. This means that this number of Nigerians may be living with diabetic retinopathy and or other complications of diabetes. Diabetic retinopathy was positively associated with age but not with sex as shown in Table 3 . However, the risk of presenting with diabetic retinopathy was higher among males.

\subsection{Limitations of the Study}

The bias of self-selection may affect the true prevalence of ocular disorders in these areas as only those who feel incapacitated by their ocular problems may be inclined to show up.

\subsection{Conclusion}

The common ocular disorders/morbidities noted in this study are significant causes of visual impairment and blindness in Nigeria. It is therefore imperative that eye care services be established and strengthened through free outreaches particularly in the remote and rural areas of Imo state in order to achieve the vision 2020 goal of eliminating avoidable blindness.

\section{Conflict of Interest}

The authors declare no conflict of interest.

\section{References}

[1] Kyari, F.I., Gudlavalleti, M.V., Sivsubramaniam, S., Gilbert, C.E., Abdull, M.M., Entekume, G. and Foster, A., Nigeria National Blindness and Visual Impairment Study Group (2009) Prevalence of Blindness and Visual Impairment in Nigeria: The National Blindness and Visual Impairment Study. Investigative Ophthalmology and Visual Science, 50, 2033-2039. http://dx.doi.org/10.1167/iovs.08-3133

[2] WHO Fact Sheet No. 282. Visual Impairment and Blindness. http://www.who.int/mediacentre/factsheets/fs282/en/

[3] Osahon, A.I., Omoti, A.E. and Otoibh’I', S.C. (2001) Free Eye Screening in the University of Benin Teaching Hospital 
at BeninCity,Nigeria. JCM, 9.

[4] Achigbu, E.O. and Achigbu, K.I. (2014) Traditional Medication Use among Out-Patients Attending the Eye Clinic of a Secondary Health Facility in Owerri, South-East Nigeria. Orient Journal of Medicine, 26, 107-113.

[5] Klauss, V. and Adala, H.S. (1994) Traditional Herbal Eye Medicine in Kenya. World Health Forum, 15, 138-142.

[6] Nwosu, S.N.N. (2002) Beliefs and Attitude to Eye Diseases and Blindness in Rural Anambra State. Nigerian Journal of Ophthalmology, 10, 16-20. http://dx.doi.org/10.4314/njo.v10i1.11901

[7] Courtright, P. (1995) Eye Care Knowledge and Practices among Malawian Traditional Healers and the Development of Collaborative Blindness Prevention Programmes. Social Science \& Medicine, 41, 1569-1575. http://dx.doi.org/10.1016/0277-9536(95)00028-6

[8] Ukponmwan, C.U. (2013) Pattern of Ocular Morbidity in Nigeria. Asian Pacific Journal of Tropical Disease, 3, 164166. http://dx.doi.org/10.1016/S2222-1808(13)60064-X

[9] Osahon, A.I., Edema, O.T., Ukponmwan, C.U., Waziri-Erameh, J., Dawodu, O.A., Omoti, A., et al. (2004) Eye Care Outreach to Rural Underserved Populations in Edo and Delta States of Nigeria. JMBR, 3, 83-90.

[10] Edema, O.T. and Okojie, O.H. (1997) Pattern of Eye Diseases in Benin City, Nigeria. African Journal of Medical Practice, 4, 86-90.

[11] Akinsola, F.B., Majekodunmi, A.A., Obowu, C.B. and Ekanem, E.E. (1995) Pattern of Eye Diseases in Adults 16 Years and above in Alimoso Local Government Areas of Lagos State. Nigerian Postgraduate Medical Journal, 2, 5661.

[12] Bastola, P. (2012) The Pattern of Ocular Morbidity, Findings from a Study Conducted in Western Remote Hilly Region of Nepal. Nepal Journal of Medical Sciences, 1, 35-38. http://dx.doi.org/10.3126/njms.v1i1.5795

[13] Kc, R.M., Ale, J.B. and Singh, S.K. (1998) Pattern of Blindness in Mechi-A Hospital Based Study in Mechi Eye Care Centre. Journal of Nepal Medical Association, 37, 422-426.

[14] Isawumi, M.A., Hassan, M.B., Asekun-Olarinmoye, E.O., Akinwusi, P.O., Adebimpe, W.O. and Alebiosu, C.O. (2013) Prevalence and Causes of Ocular Morbidity Seen among Rural Adult Population of Osun State, Southwest Nigeria. Annals of Tropical Medicine and Public Health, 6, 465-471. http://dx.doi.org/10.4103/1755-6783.127802

[15] Fotouhi, A., Hashemi, H. and Mohammad, K. (2006) Eye Care Utilization Patterns in Tehran Population: A Population Based Cross-Sectional Study. BMC Ophthalmology, 6, 4. http://dx.doi.org/10.1186/1471-2415-6-4

[16] Monsudi, K.F., Saka, E.S. and Azonobi, R.I. (2015) Pattern of Eye Diseases Present at Free Outreach in Rural Community in the Northwestern Nigeria. Sudan Medical Monitor, 10, 113-116. http://dx.doi.org/10.4103/1858-5000.171862

[17] Mehari, Z.A. (2013) A Study of Ocular Morbidity of Patients Attending Ophthalmic Outreach Services in Rural Ethiopia. International Journal of Medicine and Medical Sciences, 3, 450-454.

[18] Oyeleye, O. (1982) Mobile Unit in Nigeria. Proceeding of African Eye, Nairobi, 68-78.

[19] Nwosu, S.N. (1998) Ocular Problems of Young Adults in Rural Nigeria. International Ophthalmology, 22, 259-263. http://dx.doi.org/10.1023/A:1006338013075

[20] World Health Organization. Priority Eye Diseases. World Health Organization, Geneva.

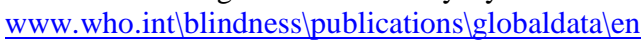

[21] Mahmoud, A.O., Olatunji, F.O., Buari, S.B. and Sanni, H. (2005) Survey of Blindness and Ocular Morbidities in Kwara State, Nigeria. Nigerian Journal of Surgical Sciences, 15, 26-31.

[22] Adegbehingbe, B.O. and Majengbasan, T.O. (2007) Ocular Health Status of Rural Dwellers in South-Western Nigeria. Australian Journal of Rural Health, 15, 269-272. http://dx.doi.org/10.1111/j.1440-1584.2007.00906.x

[23] The Nigeria National Blindness and Visual Impairment Survey 2005-2007. http://pbunion.org/Countriessurveyresults/Nigeria/Nigeria_survey_Summary_report.pdf

[24] Zerihun, N. (1994) Ocular Morbidity at a Small Eye Unit in Jimma Town, South Western Ethiopia: A Three Year Analysis. East African Medical Journal, 71, 470-472.

[25] Oputa, R.N. (2009) National Diabetes Screening Programmes. Diabetes International, 17, 9-11. 


\section{Submit or recommend next manuscript to SCIRP and we will provide best service for you:}

Accepting pre-submission inquiries through Email, Facebook, LinkedIn, Twitter, etc.

A wide selection of journals (inclusive of 9 subjects, more than 200 journals)

Providing 24-hour high-quality service

User-friendly online submission system

Fair and swift peer-review system

Efficient typesetting and proofreading procedure

Display of the result of downloads and visits, as well as the number of cited articles

Maximum dissemination of your research work

Submit your manuscript at: http://papersubmission.scirp.org/ 